\title{
Nudges in SRI: The Power of the Default Option
}

\author{
Jean-Francois Gajewski ${ }^{1}$ Marco Heimann ${ }^{1}$ (1) $\cdot$ Luc Meunier $^{2}$ \\ Received: 18 May 2020 / Accepted: 31 December 2020 / Published online: 4 February 2021 \\ (c) The Author(s) 2021
}

\begin{abstract}
We introduce nudges in order to incite investors to choose Socially Responsible Investment (SRI) funds instead of traditional funds. We have set up two online experiments with a total of 713 US retail investors, using three types of nudges to elicit their effects on investors' SRI investments level: making SRI the default investment, introducing a SRI explanation message, and priming ethical values by displaying shocking images. Making SRI the default option is the most efficient nudge to influence investors towards SRI. Its effect is twofold. First, around 50\% of investors do not opt-out of the default allocation. Second, even investors who opt-out of the default allocation invest more in SRI than those in the control group, an effect that appears driven by anchoring. Although investors subjected to both priming and message content marginally increase their SRI investment, priming or message content in isolation appears to have a non-significant influence. For choice architects who want to steer retail investors towards SRI funds, making them the default option appears to be the most powerful nudge.
\end{abstract}

Keywords Investor behavior · Nudge theory $\cdot$ Sustainable and responsible investment

\section{Introduction}

How can financial practice become more ethical? Since the economic crisis of 2008 and ongoing global concern about sustainable development goals, the need for taking measures to promote responsible finance has become a major concern. It is more difficult, however, to develop strategies and measures which help to foster the engagement of financial actors for more integer and fair business conduct.

One attempt to solve the issue is socially responsible investments (SRI): an investment practice that includes extra-financial criteria in investment decisions (Renneboog et al. 2008). While institutional signatories of the UN Principles for responsible investment show significant progress (Majoch et al. 2017), retail investors have not adopted SRI to the same degree (Forum for Sustainable and Responsible

Marco Heimann

marco.heimann@univ-lyon3.fr

Jean-Francois Gajewski

jean-francois.gajewski@univ-lyon3.fr

Luc Meunier

luc.meunier@essca.fr

1 University of Lyon, Jean Moulin, iaelyon, Magellan, Lyon, France

2 ESSCA School of Management, Aix-En-Provence, France
Investment 2018). This suggests that socially responsible mutual funds are a part of the solution to a more responsible finance but laypeople fail to invest in line with such ethical values.

From a classical economic perspective, the decision not to invest in SRI would be attributed to the outcome of a utility maximization process. However, a recent meta-analysis (Von Wallis and Klein 2015) reports evidence of equivalent performance between SR and conventional funds. This of course undermines the argument of a fundamental reason to choose classical funds over socially responsible (SR) funds.

A behavioral approach provides a different paradigm and, as we argue, can help in promoting SRI. One alternative explanation for low SRI participation is that the choice architecture in which the decision to invest is made favors the opposite choice. The framework for this explanation was first offered by Pilaj (2017) who draws on the nudge theory (Thaler and Sunstein 2008) and recommends redesigning the investment decision process for increasing socially responsible investments.

We add to the existing literature by conceiving practicable nudges and empirical validation in an experimental setting. Therefore, we first discuss behavioral nudges, i.e., modification of choice architectures, and their use for improving economic decisions. We then turn towards the choice architecture of retail investment decisions and identify potential 
barriers to SRI. For each barrier, we conceptualize a nudge aimed at overcoming the barrier. In the empirical part, we report on two experiments that test the effectiveness of the proposed nudges and explore the underlying psychological mechanisms. We conclude with implications for further behavioral research and policymakers.

\section{Nudges and Responsible Finance}

The term "nudge" comes from behavioral economics, coined by the economist Richard Thaler and the legal scholar Cass Sunstein (Thaler and Sunstein 2008), to describe a method to influence human behavior, without relying on prohibitions and commandments or altering the economic incentives. The concept in turn has been applied to various domains, including marketing communications. Unlike, classical theories that assume a homo oeconomicus (rational economic agent), nudge theory anticipates a "normal" human (Thaler 2000), who may be myopic or impulsive, place undue weight on short-term outcomes, and procrastinate, or else may be unrealistically optimistic.

Nudges are modifications of the choice environment that produce a predictable change in decisions to the benefit of the decision-maker. For example, in a cafeteria, fruits and vegetables, placed at eye level increase their consumption; cigarette packets with warnings reduce smoking. Baldwin (2014) suggests using the degree of modification of the environment to classify nudges. First-degree nudges supply simple information (e.g., reminders of the health risks of smoking); second-degree nudges exploit behavioral or volitional limitations (e.g., making smoking areas more uncomfortable); and third-degree nudges use framing strategies and emotional responses (e.g., images of the diseased lungs of cancer patients) ${ }^{1}$.

Nudges draw extensively on research in cognitive psychology (Tversky and Kahneman 1974, 1981; Kahneman 2003) and are designed to correct sub-optimal decisions. For example, in finance, nudges have helped to increase retirement savings (Gunaratne and Nov 2015), improve portfolio holdings (Ackert et al. 2016), or reduce financial illiteracy (Chater et al. 2010). Improvements of individuals' decisions that benefit the individuals and society are central to nudging.

Following Pilaj (2017), we argue that SRI acts as a lever for investors to promote higher levels of CSR in firms, in turn leading to a more sustainable development. Thus, SRI provides an opportunity to foster values of interest to individuals and the society.

\footnotetext{
${ }^{1}$ In this paper, we are closer to the framework given by Pilaj (2017).
}

In addition, both the Eurosif (2018) and the ECMI Task Force on Asset Allocation (2020) recognize that individuals display a firm desire to invest in a sustainable manner. As pointed out in Vyvyan et al. (2007), there is, however, a strong attitude-behavior gap. A 2018 BNP Paribas survey on 5000 retail investors from 5 European countries underlines that the willingness to invest "at least a small part of the portfolio in SRI" ranges from 52\% in the Netherlands to $80 \%$ in Italy. The actual use of SRI was between 5 and $7 \%$ for the individuals in these 5 countries. Likewise, retail investors express moral values in experiments (Rubaltelli et al. 2015) and according to Riedl and Smeets (2017) social preferences are mirrored in investor holdings data. In surveys, investors also explicitly indicate their desire to increase the share of SRI in their portfolios (Valor and Fernandez 2009).

This attitude-behavior gap can be explained by the framework of Pilaj (2017), who underlines that individuals need to overcome several barriers if they are to invest in SRI. As a result, investment decisions are currently directed away from ethical investing. Some people who invested in conventional funds did so mostly by default and would have considered themselves better off with investments in SRI that suit their personal values.

Nudges promoting investment in SRI could thus improve satisfaction regarding investment allocation while preserving the freedom of choices of the others. Even more importantly, nudges promoting investment in SRI would improve societal outcomes by fostering sustainable development (Pilaj 2017).

\section{Moral Values in Retail Investment Decisions}

Extant research details various demographic factors, investor motivations, social preferences, and the financial benefits to explain investment in SRI (Nilsson 2009, 2010; Riedl and Smeets 2017), though few studies address active policy measures for encouraging SRI investments by retail clients. In an effort to build on previous theoretical research on nudges for SRI (Pilaj 2017), we choose to focus on retail investors. As pointed out in the Eurosif (2018) report, while institutional investors have at first been pioneers in adopting SRI investment, the interest by retail investors is growing, as evidenced by the nine-fold increase in demands for SRI products from this segment in Europe over the past 4 years. As put by Eurosif p.76, it is "increasingly recognized by the industry that retail investors are key to ensuring that sustainable investing becomes truly mainstream." Undoubtedly, retail investors' demand for SRI also results in an incentive for investment companies to increase SRI supply (Pilaj 2017). Nonetheless, as we will depict, various barriers prevent them to play that role at the moment. 


\section{Barriers to Responsible Investing and Nudges}

While there might not be material constraints to retail investment choices the way investment options are presented will influence the investors' choice. Accordingly, we argue with Pilaj (2017) and Paetzold and Busch (2014) that the decision environment of retail investors introduces barriers for responsible investment. In the following, we consider three common barriers to SRI which are derived from ethical decision-making literature: recognition of the ethical choice, decision complexity of responsible investment, and attitude toward the ethical dimension of investments. Moreover, we propose a nudge to overcome each of the barriers.

\section{Awareness of the Ethical Choice}

A first barrier is that investors might not recognize that an investment decision actually represents an ethical choice. When investing, people are primarily set to think about money. Consequently, their decisions reflect a mental state that directs them away from decision factors which are not directly linked to finance.

Research in the mental model approach to decisions has explicitly distinguished between monetary and social markets in which people behave fundamentally differently (Heyman and Ariely 2004). In money markets, people's behaviors are characterized by a monotonic relationship between payment and effort, but in social markets, effort is largely independent of compensation levels. Vohs et al. (2008) similarly suggest that money triggers market pricing expectations, as a mental framework that guides behavior. People who adopt a market pricing framework tend to exhibit diminished ethical behavior. For instance, when Vohs et al. (2006) reminded participants of money (vs. play-money reminders or controls), they were less likely to help others or ask for help and tended to prefer working and playing alone. In a business decision setting, less ethical outcomes are more frequent (Kouchaki et al. 2013). Since people easily lose their "moral compass" (Mazar et al. 2008; Gino et al. 2011; Shalvi et al. 2012; Bazerman and Sezer 2016), financial market settings are less prone to ethical decisions.

Welsh and Ordonez (2014) show that dishonesty diminishes when participants are primed to increase moral awareness. Several other studies concur, such as when Kouchaki and Smith (2014) find that awareness of morality increases honesty in performance self-reports, Shu et al. (2011) indicate that participants' moral awareness increases their honesty, or Gino et al. (2011) assert that greater moral awareness leads to less fraud. Models that account for ethical recognition in SRI contexts draw on the process of ethical decisionmaking in organizations (Jones 1991), in which recognizing the moral issue is the first step, related to moral intensity (May and Pauli 2003). In applying an issue-contingent model of SRI, Hofmann et al. (2007) survey of 286 investors determines that recognition of the moral issue increases when these investors perceive greater moral intensity.

A nudge to overcome this barrier would aim to increase awareness of the ethical issue and could use priming techniques. In psychology, priming refers to efforts to influence the processing (cognition) of a stimulus (Meyers 2008). There are also many variants of the general priming concept. For example, if a prime is not presented long enough, it cannot be consciously perceived. The resulting subliminal primes can achieve effects but also contradict the principle that nudges should be transparent and not misleading (Thaler 2015). Conscious priming instead fits with the requirements of nudges. Priming people to think about money can lead to less ethical choices (Vohs et al. 2006; Kouchaki et al. 2013). Priming for ethical values might, instead, make ethical concerns more accessible. For example, descriptions of the negative ethical impacts of business activities can be effective primes. Images of underprivileged beneficiaries can increase charitable donations (Isen and Noonberg 1979; Perrine and Heather 2000), potentially due to feelings of guilt (Chang 2011). Specifically, in SRI, Glac (2009) primed investors for an "expressive" decision frame and found that this reduced significantly the percentage of participants not choosing the SRI option. Showing investors images of corporate misconduct and appealing to feelings of guilt may influence their SRI investments, reflecting the third-degree nudges in Baldwin's (2014) classification.

H1 Investors consciously primed to consider ethical impacts increase the money they allocate to SRI, as compared to a control group receiving no nudge.

\section{Increased Complexity of the Investment Decision}

A second barrier to responsible investment is that the ethical dimension adds to already complex stock market investments decision. Even in conventional settings, investors must determine their appetite for risk-adjusted returns (Markowitz 1952), which is both difficult to assess and strongly variable (Schooley and Worden 1996; Filbeck et al. 2005; Wang and Hanna 1997). Adding an ethical preference dimension to the choice increases its complexity even further. In particular, SRI offers are increasingly common (Nilsson 2010), yet definition of SRI is heterogeneous (Sandberg et al. 2009). Moreover, the relationship among SRI, risk, and returns is unclear (Ambec and Lanoie 2008; Bauer et al. 2007).

The theory of planned behavior (TPB, Ajzen 1991) argues that complexity is a major concern for decisionmaking. In essence, complexity reduces people's perceived behavioral control over their decisions. For example, among 
the high net worth people whom Paetzold and Busch (2014) interviewed to understand barriers to SRI, a lack of ethical information or uncertainty about how to act on it limited perceived control. Complexity increases with the absence of information or prior knowledge about actions and can lead to the creation of a barrier.

Multiple factors are considered in decisions of SR investors (Beal et al. 2005; Hummels and Timmer 2004). The complexity created by the combination of financial and moral aspects can overwhelm investors with an abundance of information. This abundance might result in resignation because people tend to limit their cognitive efforts to be informed (Berg 2007). In other words "a systematic behavior in complex situations is to not decide" Sunstein (2015), i.e., to stay with the default.

The default effect results from an excessive preference for the default option. In fact, this situation of excess goes up to a point where the decision-maker does not take any active decision (Tversky and Kahneman 1992; Kahneman 2011). A related effect is the status quo distortion, which describes the excessive preference for the status quo rather than any change (Kahneman et al. 1991). Various explanations for these effects, include the preference for convenience or diminished cognitive effort (Dinner et al. 2011; Gigerenzer 2008; Johnson and Goldstein 2003; Johnson 2008), avoidance of transaction costs (Samuelson and Zeckhauser 1988; Ayres and Gertner 1989), loss aversion (Tversky and Kahneman 1991), perception of the default option as policymaker recommendation (McKenzie et al. 2006), change of meaning (Davidai et al. 2012), and omission bias (Landman 1987; Ritov and Baron 1992; Baron and Ritov 1994).

Therefore, if people thus tend to accept default options in complex situations, a nudge to overcome the complexity barrier could be to make SRI the default investment choice. This nudge would fall into the second-degree category of Baldwin's (2014) classification.

H2 Making SRI the default investment decision increases the money allocated to SRI, as compared to a control group receiving no nudge.

\section{Attitude Towards Responsible Investment}

Finally, the third barrier to SRI investments is the attitude toward the ethical dimension of investments. Recognizing an ethical choice is not a sufficient condition for ethical behavior; the investor also must have a positive attitude towards and endorse the ethical option.

Even if investors seek information about the social responsibility of their investments (Hummels and Timmer 2004; Hockerts and Moir 2004), financial considerations strongly influence their choices (Jansson and Biel 2009). Since the empirical debate about the relative performance of SRI is not settled (Ambec and Lanoie 2008; Bauer et al. 2007) investors suffer at least uncertainty about the financial benefits or costs of SRI. Moreover, some investors could even see SRI as a threat to their financial returns (Lewis and Mackenzie 2000; Nilsson 2008) and adopt a negative attitude towards SRI.

Attitudes reflect assessments of objects and can support social adaptation through identification and distancing processes (Ajzen 2001). For example, Lewis and Webley (1994) show that positive green attitudes can predict investments in environmentally themed funds and Hofmann et al. (2008) use a four-item attitude scale to successfully predict investment intentions.

Attitudes toward responsible behavior result from individual evaluations of performing the behavior (Hofmann et al. 2008; Ajzen 1991). If retail investors perceive that the outcome of investing in SRI reduces returns, increases risk, or simply lacks the promised impact on business practices, then conventional funds will be their choice.

To overcome this barrier reminders of what SRI is and clarifying its relation to financial performance may nudge investors toward more responsible investments. This nudge would fall into the first-degree category of Baldwin's (2014) classification.

H3 Investors reminded of SRI concepts increase the money they allocate to SRI, as compared to a control group receiving no nudge. Investors reminded of SRI concepts increase the money they allocate to SRI, as compared to a control group receiving no nudge.

On the whole, we expect that priming investors with images of corporate misconduct, making SRI the default, and clarifying information about SRI will nudge investors towards it. While each nudge could technically be implemented individually we also investigate their interaction to provide further robustness. Keeping the same goal to mind, we introduce individual characteristics of investors known to correlate with the decision to invest in SRI.

\section{Correlates of SR Investment Decisions}

In this subsection, we define other determinants of SRI, we intend to use as control variables.

\section{Altruism}

People's motives for prosocial behavior, such as donating to charities or buying green products (Ariely et al. 2009), may stem from their altruism, defined as a personal value that prioritizes the well-being of others (Henrich et al. 2005; Griskevicius et al. 2010; Delton et al. 2011). The altruistic 
personality trait refers to the enduring tendency of someone to feel compassion for others and do them a favor (Penner and Finkelstein 1998). As a trait, altruism is a dispositional determinant of prosocial behavior, which can be measured with psychometric personality tests like the agreeability dimension of the Big 5 (Barrick and Mount 1991). That is, people who score high on agreeability also tend to treat others with understanding, benevolence, and compassion; strive to help others; and believe that others will be similarly helpful toward them. They tend to exhibit interpersonal trust, cooperativeness, and compliance. To measure dispositional altruism, we use the altruism scale from Goldberg et al.'s (2006) inventory (see Appendix A.1).

\section{Risk Aversion}

Risk propensity is the tendency to take or avoid risk in a specific domain (e.g., investment). More specifically, risk-avoiders are more likely to overestimate the likelihood of losses relative to gains, hence, they require a higher probability of gains to tolerate risk exposure (Schneider and Lopes 1986). Following Riedl and Smeets (2017), we used risk aversion as a control variable. To measure risk tolerance, we use a lottery (see Appendix A.2).

\section{Expertise Factors}

Consumer expertise can have significant effects on decisionmaking (Alba and Hutchinson 1987; Berg 2007). We argue that while consumers lack awareness of their joint responsibility for the environment and society, higher financial literacy could be linked to a higher awareness of the impact of investment decisions on environment and society. We present the items used to gauge financial literacy and expertise in Appendix A.3, which will be used as controls in the regressions.

\section{Demographics}

We consider several sociodemographic variables. Capon et al. (1996) find that clusters based on age and gender differ significantly in consumption of financial services; younger households tend to hold investment portfolios associated with a higher level of risk (Pålsson 1996). Such differences refer to general investment behavior, but we know of a few studies that investigate the influence of sociodemographic factors on SRI (Mclachlan and Gardner 2004; Williams 2007; Nilsson 2009). This limited evidence implies that SRI consumers tend to be younger (Diamantopoulos et al. 2003), female (Laroche et al. 2001; Lee 2009), and better educated (Chan 1999).

\section{Experiment 1}

\section{Methods}

We use a sample of 331 retail investors from the United States, $45 \%$ of whom were women, aged 37 years on average $(\mathrm{SD}=11.7)$. Participants were recruited via Amazon Mechanical Turk and paid $\$ 0.50$. This approach has been used in similar studies (Welsh and Ordonez 2014). Following Buhrmester et al. (2011) and Paolacci et al. (2010), we used attention checks and screened for highly unlikely response sequences which excluded 55 (14\%) from the initial 386 recruits.

After reading general instructions about the importance of providing thorough answers to ensure research quality, they were invited to play an investment game in which they had to allocate $10.000 \$$ between four mutual funds (see Appendix A.4). While all funds were equally efficient in terms of risk and return, only one of them was described as socially responsible. Furthermore, one of the funds, described as an index fund, had the same risk-return profile as the SRI fund.

Participants were randomly assigned to one of eight experimental groups. One control group was not nudged. Three groups saw simply one nudge: the SRI default, the SRI message or priming (see Appendices A.5, A.6 and A.7). The four additional groups consisted in combinations of several nudges:

- message \& priming

- message, priming \& default

- priming \& default

- message \& default

We introduced these combinations in order to explore potential interaction effects. In particular, this enables us to test the robustness of the main effects, by assessing whether an additional change in the choice environment can lead the nudge to backfire.

After playing the investment game participants answered the questions about altruism, risk aversion, expertise, and their demographic profile discussed in "Correlates of SR Investment Decisions."

\section{Results}

We first regressed ${ }^{2}$ the overall percentage invested in SRI on dummy variables for the nudges and various sociodemographic variables.

\footnotetext{
${ }^{2}$ We used robust standard errors for all the ordinary least squares regressions, in response to evidence of heteroscedasticity in the regression errors.
} 
Table 1 Regressions, Experiment 1

\begin{tabular}{|c|c|c|c|c|c|c|c|c|}
\hline & \multirow{2}{*}{\multicolumn{2}{|c|}{$\begin{array}{l}\text { Inv. SRI } \\
\text { Overall Reg. }\end{array}$}} & \multirow{2}{*}{\multicolumn{2}{|c|}{$\begin{array}{l}\text { Step 1-Opt-In- } \\
\text { Probit } \\
\text { Exposed to } \\
\text { Default }\end{array}$}} & \multirow{2}{*}{\multicolumn{2}{|c|}{$\begin{array}{l}\text { Step 2-Inv. SRI } \\
\text { Refused Default }\end{array}$}} & \multirow{2}{*}{\multicolumn{2}{|c|}{$\begin{array}{l}\text { Step 2-Inv. SRI } \\
\text { Refused Default }\end{array}$}} \\
\hline & & & & & & & & \\
\hline & Coef. & $p$-val. & Coef. & $p$-val. & Coef. & $p$-val. & Coef. & $p$-val. \\
\hline Message (M) & 4.701 & 0.192 & & & & & & \\
\hline M + Default (D) & $41.664 * * *$ & 0.001 & & & & & $11.986 * * *$ & 0.008 \\
\hline $\mathrm{M}+\mathrm{D}+$ Priming $(\mathrm{P})$ & $38.311 * * *$ & 0.001 & & & & & -1.967 & 0.704 \\
\hline$M+P$ & $9.160 * *$ & 0.014 & & & & & & \\
\hline D & $45.800 * * *$ & 0.001 & & & & & $8.364 * *$ & 0.041 \\
\hline $\mathrm{D}+\mathrm{P}$ & $46.524 * * *$ & 0.001 & & & & & $15.674 * * *$ & 0.010 \\
\hline $\mathrm{P}$ & 1.911 & 0.586 & & & & & & \\
\hline Seen Default & & & & & $8.759 * * *$ & 0.007 & & \\
\hline Age & -0.163 & 0.273 & -0.007 & 0.459 & -0.161 & 0.218 & -0.109 & 0.393 \\
\hline Gender & 1.336 & 0.695 & -0.185 & 0.392 & 2.065 & 0.558 & 4.262 & 0.238 \\
\hline Univ. & -4.395 & 0.245 & $-0.388^{*}$ & 0.083 & 1.494 & 0.643 & 0.036 & 0.991 \\
\hline Ever Inv. & 4.342 & 0.281 & 0.124 & 0.632 & 3.994 & 0.341 & 3.634 & 0.376 \\
\hline Fin. Lit. & 5.681 & 0.137 & -0.047 & 0.834 & $6.962^{*}$ & 0.059 & $6.867 *$ & 0.055 \\
\hline Altruism & $0.787 * * *$ & 0.004 & $0.027 *$ & 0.098 & $0.455^{*}$ & 0.070 & $0.511 * *$ & 0.049 \\
\hline Risk Aversion & 0.893 & 0.505 & 0.007 & 0.935 & 0.959 & 0.439 & 1.517 & 0.214 \\
\hline Constant & 9.090 & 0.462 & 0.360 & 0.648 & 7.030 & 0.518 & 1.585 & 0.890 \\
\hline$N$ & 331 & & 161 & & 132 & & 132 & \\
\hline (Pseudo) $R$ & 0.349 & & 0.059 & & 0.134 & & 0.203 & \\
\hline
\end{tabular}

The first, third, and fourth regressions are simple ordinary least squares with robust standard errors, and the second is a probit regression. The first regression includes the percentage invested in SRI as the dependent variable. The nudges are assessed in comparison with the control group. The second regression deals with the determinants for the opt-in decision. The third and fourth regressions use the percentage invested in SRI as a dependent variable, but they only include participants who refused the default allocation (and the control group, for comparison)

$*$, **, and *** indicate, respectively, significance at the $10 \%, 5 \%$, and $1 \%$ levels
The results are presented in Table 1. The default nudge, presented with or without other nudges, shifts the percentage of the portfolio invested in the SRI funds upward compared with a control group. The effect is both statistically $(p<0.01)$ and economically significant. On average, the shift ranged from $+38.3 \%$ among the participants who saw all three nudges to $+46.5 \%$ for default and priming. Being presented only with the default nudge resulted in $+45.8 \%$ of investment in SRI; the default plus message condition resulted in $+41.7 \%$.

The group subjected to both the message and priming Nudges also increased their investment in SRI $(+9.2 \%$ versus the control group, $p=0.014)$. Alone, neither the message nor the priming nudge is significant in this regression, after taking the covariates into account.

We controlled for gender, age, risk aversion, experience investing in the financial markets, financial literacy, having a bachelor's or a higher degree, and altruism. Higher altruism scores were linked with more investments in SRI.

Figure 1 illustrates the two (potentially additive) reasons for the meaningful influence of the default nudge. That is, participants might choose the default option (Step 1), or they could invest more in SRI after they refuse the default (Step 2).

Noting the strong statistical and economic significance of the default nudge, in combination with other nudges or not, we investigate its effect further. With a probit regression of the propensity to choose the default (Step 1), we find

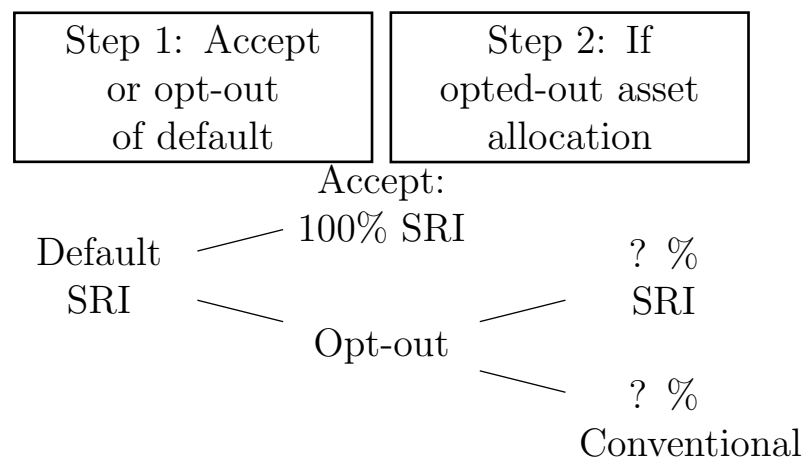

Fig. 1 Two-step SRI decision process 
that $47.8 \%$ of participants accepted the default allocation if they saw a nudge that included it. No significant difference in acceptance arises among the various conditions with a default nudge, so we drop it from the regression. The results in Table 1 indicate that more altruistic people tend to be significantly more likely to choose the default allocation (marginal significance, $p<10 \%$ ). Having a bachelor's degree or higher reduced the probability of accepting the default allocation (marginal significance, $p<10 \%$ ).

The third regression includes participants who refused the default allocation (Step 2). With the third regression, we determine that respondents who were exposed to any default nudge, but refused it, invested significantly more than the control group in SRI.

A fourth regression (Table 1) details this result for each nudge conditions. That is, for the groups exposed to just the default nudge, the combination of default plus priming, or default plus message nudges who rejected the default allocation still invested more in SRI than the control group. Therefore, beyond the direct effect of the default investment (i.e., people accept the default $100 \%$ of investment in SRI), an indirect effect of this nudge arose, even among people who refused the default option. This result might reflect an anchoring effect such that people subjected to a proposed $100 \%$ investment in SRI funds revise their chosen investments in such funds upward. Again, more altruistic people tend to invest more in SRI. Financial literacy also proves marginally significant ( $p=0.055$ ). More financially literate respondents appear to invest more in SRI.

However, the greater investment in SRI does not arise in the combination of all three nudges (default + message + priming). Compared with the control group, participants who saw all three nudges and also rejected the default option displayed a slightly lower investment in SRI (Table 1, although non-significant).

Yet a Wald test of equality indicates a significant difference. Participants who refused the default allocation and were subjected to all three nudges invested significantly less than those subjected to the default nudge ( $p=0.062)$, the default nudge plus the message ( $p=0.021)$, or the default nudge plus the priming ( $p=0.001)$.

In this section, we have provided the results of two separate regressions (or two-part model), to reveal the actual response with selection. An alternative approach might apply the Heckman two-step model to analyze the data and correct for selection. When we do so, the main results remain unchanged (see Table 8 in Appendix B).

\section{Discussion}

The default nudge, on its own or most combinations including it, has a very strong impact on the percentage of investment in SRI. This effect is mainly driven by people who accept the default allocation, though a positive impact also exists among those who decide to define their own allocation.

The intriguing results for the priming nudge indicate that it does not exert significant effects on its own. The combination of the three nudges also does not encourage people who had opted out of the default option to invest more in SRI.

We interpret these results in the light of Baldwin's (2014) classification of the degrees of different nudges. That is, some participants, confronted with an overly intense degree of nudging, might perceive an intrusive manipulation attempt, which evokes their negative reactance.

We tested this assertion in experiment 2 by measuring participants' emotions after they had seen the nudges, with the prediction that participants who had seen the priming nudge would be more irked by this manipulation attempt than others.

\section{Experiment 2}

Acceptance of the default might be driven by the default effect, but it also might reflect an actual preference for SRI. Therefore, in experiment 2, we include a default allocation of $100 \%$ in an index fund, that offers the same risk and return as the SRI, so we can disentangle the impact of the nudge versus the SRI.

With this second experiment, we also address the positive effect of the default nudge among participants who choose their own allocation in terms of a potential anchoring explanation. Specifically, adopting a methodology proposed by Jahedi et al. (2017), we pinpoint participants' propensity to anchor, then correlate this propensity with the percentage invested in SRI by participants who choose something other than the default.

\section{Method}

Out of the 508 participants in Experiment 2, 381 (75\%) passed the attention check ( $48 \%$ female; mean age $=$ 39 years; $\mathrm{SD}=12.0$ ). They were recruited via Amazon Mechanical Turk, paid \$0.50, and from the United States.

We used materials from experiment 1 but also addressed three issues. First, we included a "fake" nudge, in which the default allocation is $100 \%$ assigned to a conventional fund. This allows us to distinguish between the effect of the default nudge which is due to the inherent merit of the nudge and the part which is linked to the interest of the investor for SRI. Second, we explored how the nudges affected investors' emotions (see Appendix A.9). We assessed several emotions and self-beliefs that could be associated with exposures to the nudges in this study, namely: interested, better informed, happy, guilty, sad, annoyed, irked, and nothing (as a control). 
Table 2 Investment in SRI-Experiment 2, overall regression

\begin{tabular}{lll}
\hline & Coef. & $p$-val. \\
\hline Message (M) & 1.959 & 0.647 \\
M + default SRI (D) & $44.851^{* * *}$ & 0.001 \\
M + P & $8.162^{*}$ & 0.067 \\
M + D + priming (P) & $46.457^{* * *}$ & 0.001 \\
D & $39.120^{* * *}$ & 0.001 \\
D + P & $53.383^{* * *}$ & 0.001 \\
P & 3.457 & 0.410 \\
Default conventional & $-7.993^{*}$ & 0.075 \\
Altruism & $0.784^{* * *}$ & 0.001 \\
Age & -0.054 & 0.666 \\
Men & -3.440 & 0.267 \\
Ever invested & $8.992^{* *}$ & 0.015 \\
Fin. Lit. & -0.433 & 0.894 \\
Univ. & -1.705 & 0.614 \\
Risk aversion & -0.262 & 0.847 \\
Constant & 12.207 & 0.257 \\
$N$ & 381 & \\
$R$-square & 0.402 & \\
\hline
\end{tabular}

This robust ordinary least squares regression includes the entire sample. All the nudge coefficients are relative to the control group

$*, * *$, and $* * *$ indicate, respectively, significance at the $10 \%, 5 \%$, and $1 \%$ levels

Third, we included a measure of investors' tendency to exhibit an anchoring bias, using the approach proposed by Jahedi et al. (2017).

\section{Results}

\section{Replicating the Experiment 1 Findings}

As we detail in Table 2, the default nudge in Experiment 2 (alone or in any combination) increases SRI $(p<0.01)$. The number of participants who simply accept the SRI default option (in combination or not) also is similar: $51.4 \%$ in Experiment 2 and $47.8 \%$ in Experiment 1 (non-significant difference). The default choice that invested everything in a conventional index fund reduced investment in SRI relative to the control group (marginal significance, $p<10 \%$ ). The combination of the message and Priming nudges proved marginally significant ( $p=0.067)$, yet neither nudge was significant on its own. Altruism is significantly associated with higher investment in SRI. It is also true for people who have invested in the stock market previously, in a finding that we did not uncover in Experiment 1.
Table 3 Probability to Opt-In the default

\begin{tabular}{|c|c|c|c|c|}
\hline & \multicolumn{2}{|c|}{ Probit-Opt-In } & \multicolumn{2}{|c|}{ Probit-Opt-In } \\
\hline & Coef. & $p$-val. & Coef. & $p$-val \\
\hline DefaultSRI & 0.271 & 0.236 & -0.306 & 0.453 \\
\hline Altruism & & & -0.032 & 0.314 \\
\hline DefaultSRI*Altruism & & & $0.063 *$ & 0.062 \\
\hline Age & 0.006 & 0.459 & 0.003 & 0.651 \\
\hline Men & 0.022 & 0.906 & 0.090 & 0.640 \\
\hline Ever invested & $0.473 * *$ & 0.024 & $0.432 * *$ & 0.042 \\
\hline Fin. Lit. & -0.071 & 0.710 & -0.143 & 0.476 \\
\hline Univ. & 0.089 & 0.661 & 0.099 & 0.629 \\
\hline Risk aversion & -0.016 & 0.820 & -0.009 & 0.903 \\
\hline Constant & $-1.070^{*}$ & 0.098 & -0.693 & 0.369 \\
\hline$N$ & 212 & & 212 & \\
\hline Pseudo $R$ & 0.024 & & 0.045 & \\
\hline
\end{tabular}

The probit regressions highlight the determinants of the default optin. They only include participants who saw one of the default nudges $*, * *$, and $* * *$ indicate, respectively, significance at the $10 \%, 5 \%$, and $1 \%$ levels

\section{Default Effects or SRI Conviction?}

Among all the participants who are offered the conventional fund as the default nudge, $44 \%$ of them accepted the default (100\% of investment in the conventional fund). By comparison, among all the participants who are offered any combination of the other nudges (default SRI, priming, message), $51 \%$ of them decide to invest in SRI. The difference between these two percentages is not significant $(p=0.38)$. The percentages of respondents who accepted the default SRI (presented alone) or the default conventional fund are roughly the same: $43 \%$ for the default SRI and $44 \%$ for the default conventional fund.

Comparing all forms of default SRI (combining them all by using dummies) against the default conventional in probit regressions aiming at predicting the opt-in decision as below proved non-significant as well. Therefore, the increased investment in SRI in response to the default SRI nudge appears driven mainly by the inherent merits of nudging, not the appeal of SRI context.

As in Experiment 1, altruism relates positively and significantly to the propensity to opt-in to the SRI default (marginal significance, $p=0.062$, see the interaction in the second regression in Table 3).

\section{Opt-Out and SRI: Anchoring Effect?}

The results in Table 4 refer to participants who opted out from the default option. When SRI is the default option, we find a positive impact in the amount invested in SRI, compared with both the control group and the conventional 
Table 4 Regressions on the Opt-Out Population \& Anchoring Effect

\begin{tabular}{|c|c|c|c|c|c|c|}
\hline & \multirow{2}{*}{\multicolumn{2}{|c|}{$\frac{\text { Investment in SRI }}{\text { Opt-Out Pop. \& Control }}$}} & \multicolumn{2}{|c|}{ Investment in SRI } & \multicolumn{2}{|c|}{ Investment in SRI } \\
\hline & & & Opt-Out Po & \& Control & Opt-Out Pop & tion \\
\hline & \multicolumn{2}{|c|}{$\begin{array}{l}\text { Compared to Controls } \\
\text { and Def. Conv. }\end{array}$} & \multicolumn{2}{|c|}{ Compared to Controls } & \multicolumn{2}{|c|}{$\begin{array}{l}\text { Default SRI } \\
\text { Compared to Def. } \\
\text { Conv. }\end{array}$} \\
\hline & Coef. & $p$-val. & Coef. & $p$-val. & Coef. & $p$-val. \\
\hline M + Default SRI (D) & & & 6.153 & 0.229 & & \\
\hline $\mathrm{M}+\mathrm{D}+$ Priming $(\mathrm{P})$ & & & 7.456 & 0.166 & & \\
\hline D & & & 7.933 & 0.110 & & \\
\hline $\mathrm{D}+\mathrm{P}$ & & & $22.919 * *$ & 0.002 & & \\
\hline Default Conventional & & & 3.860 & 0.509 & & \\
\hline Default SRI & $10.084 * * *$ & 0.005 & & & -4.746 & 0.575 \\
\hline Anchoring & & & & & $-0.339 *$ & 0.059 \\
\hline Default SRI * Anchoring & & & & & $0.519 * *$ & 0.023 \\
\hline Altruism & 0.442 & 0.106 & $0.494 *$ & 0.092 & 0.580 & 0.102 \\
\hline Age & -0.186 & 0.247 & -0.185 & 0.227 & 0.040 & 0.854 \\
\hline Men & -6.246 & 0.102 & -4.990 & 0.195 & -6.056 & 0.198 \\
\hline Ever Invested & 0.519 & 0.916 & -0.720 & 0.890 & -7.318 & 0.245 \\
\hline Fin. Lit. & -1.287 & 0.739 & -2.530 & 0.528 & 0.985 & 0.837 \\
\hline Univ. & -5.845 & 0.186 & -3.758 & 0.402 & $-13.873^{* *}$ & 0.014 \\
\hline Risk Aversion & 0.335 & 0.803 & 0.043 & 0.974 & -1.609 & 0.352 \\
\hline Constant & $38.135 * * *$ & 0.005 & $36.170 * * *$ & 0.007 & $56.438 * * *$ & 0.002 \\
\hline$N$ & 152 & & 152 & & 106 & \\
\hline$R^{2}$ & 0.107 & & 0.158 & & 0.187 & \\
\hline
\end{tabular}

The ordinary least squares regressions indicate the determinants of SRI investment in the Opt-Out population. In regressions 1 and 2, we compare the opt-out population with the control group. In the third regression, using robust standard errors, we consider the participants who saw the default nudge. People with a higher anchoring propensity invest less in SRI if they have been subjected to the $100 \%$ default conventional fund nudge, and comparatively more in SRI if they have been subjected to the $100 \%$ default SRI nudge

$*, * *$, and $* * *$ indicate, respectively, significance at the $10 \%, 5 \%$, and $1 \%$ levels default option ( $p<0.01$, result robust to two-step Heckman procedure, see Table 8 in Appendix B). If participants opted out of the default SRI option, they invested about $+10 \%$ more in the SRI fund. For each nudge separately, the results are mostly shy of statistical significance. Only the combination of the default and priming nudges drove significantly higher investment in SRI in the opt-out population compared with the control group $(+23 \%, p<1 \%)$. The default SRI alone or in other combinations prompted only a non-significant increase of around $+7 \%$ of investment in SRI compared to the control group ( $p$ between 0.11 and 0.23 ).

In line with our predictions, we found a significant interaction between the propensity to anchor and having seen the default SRI nudge. For the same level of anchoring propensity, people who had seen the default SRI nudge invested significantly more in the SRI funds. Our model-based prediction indicates that someone displaying a strong anchoring effect ( +1 standard deviation above the mean) would invest $21 \%$ more in SRI after seeing the default SRI nudge rather than a default conventional nudge. Accordingly, we assert that the default nudge has both a main effect (opt-in) and a indirect effect among those who opt-out, linked to anchoring effects.

\section{Beliefs and Emotions}

Table 5 shows the average emotion scores for the different groups we test. In all the nudge groups (including the default conventional nudge), participants indicate a higher level of self-declared emotions than the control group (see regression in Table 6 on "feeling nothing particular," $p<0.01$ ). However, the effect also depends on the nudge, such that participants subjected to priming alone were significantly more irked and annoyed than the control group $(p<0.01$ in both cases). They also declared feeling sadder and guiltier $(p<0.01)$. It appears that this nudge is too intense and prompted rejection reactions. The regression in Table 7 in Appendix B adds the "Irked" variable and reproduces the effects in Table 2, except that when they feel irked, 
Table 5 Beliefs and emotionsnudges in isolation

\begin{tabular}{lllllllll}
\hline Nudge average & Irked & Annoyed & Guilty & Sad & Nothing & Interested & Happy & Informed \\
\hline Control & 2.33 & 2.41 & 2.04 & 2.09 & 3.85 & 3.22 & 2.78 & 2.80 \\
Priming & $3.61 * * *$ & $3.27^{* * *}$ & $3.09 * * *$ & $3.82^{* * *}$ & $2.79 * * *$ & 3.09 & 2.33 & 2.85 \\
Message & 2.11 & $1.96^{*}$ & 2.00 & 1.98 & $2.96 * * *$ & $3.98^{* * *}$ & $3.73^{* * *}$ & $4.18^{* * *}$ \\
Default & 2.14 & 2.20 & 1.93 & 1.82 & $3.16^{*}$ & $3.86^{* * *}$ & $3.20^{* * *}$ & $3.80^{* * *}$ \\
Default index & $1.74^{* *}$ & $1.69 * * *$ & 1.79 & 1.69 & 2.92 & $3.97 * * *$ & $3.67 * * *$ & $3.90^{* * *}$ \\
\hline
\end{tabular}

We display in this table the mean of the emotions declared by participants after the experiment, for all Nudges alone (that is, participants having faced more than one Nudges are not taken in consideration in that table). Stars are used to underline significant differences relative to the control group, according to a $t$-test

$*, * *$, and $* * *$ indicate, respectively, significance at the $10 \%, 5 \%$, and $1 \%$ levels participants allocate less money to SRI (marginal significance, $p<10 \%)$.

Participants exposed to priming, whether alone or in combination with the default or the message nudges, also feel significantly more sad and guilty. Overall, participants subjected to priming alone are the only group to display much more negative feelings than the control group ${ }^{3}$.

Still, the negative reactions attached to priming (in particular, being irked and annoyed) appear to be dulled by the presence of other Nudges, which instead tend to evoke positive feelings. Participants believe they are better informed and more interested when they encounter either the default or the message nudges $(p<0.01)$, and these effects spill over to the combinations that include them ${ }^{4}$.

Overall, Experiment 2 confirms the strong positive effect of the default nudge and any combination including it on SRI.

\section{General Discussion and Conclusion}

Our research points that in the context of investment selection, a default nudge strongly affects retail investors' decision in favor of the default option, independently of whether this option is an SRI fund or a conventional investment. In Experiment 2, participants who saw a default nudge that implied a $100 \%$ conventional investment accepted it just as much as those who saw the default SRI nudge. In this sense, our results emphasize that default nudges represent particularly appealing tactics and topics of research in various finance domains.

Furthermore, the default nudge (100\% SRI) increased SRI in both experiments, even if people did not accept the

\footnotetext{
3 We considered irked, annoyed, guilty, and sad to be negative feelings and interested, happy, and informed to be on the opposite rather positive.

${ }^{4}$ Except for the combination of message and priming, which failed to reach significance in the case of being interested.
}

$100 \%$ allocation. We explain this effect based on the anchoring theory and offer initial evidence that an anchoring bias arises. Participants, who display a rather strong anchoring bias (+1SD above the mean) and choose not to accept the default SRI, still invest $21 \%$ more in SRI compared with those who refused a default allocation of $100 \%$ in a conventional fund.

Some limitations and paths for future research should be highlighted. First, our experiments show that overly strong nudges can evoke negative reactance effects. In particular, the poor efficacy of our negative priming nudge, alone or in combination with other nudges, appears to result from its strong negative valence and propensity to irk participants. Subtler nudges (i.e., first- or second-degree, in Baldwin's 2014 classification) provide better outcomes. Future research could, however, investigate the effect of positive priming. Instead of displaying negative images associated with the text "Do you want to profit from this," a choice architect could display positive images associated with a message such as "Do you want to support this?".

Second, regarding our sample, MTurk respondents are depicted as reasonably representative of the US population by Buhrmester et al. (2011) and Paolacci et al. (2010). As pointed out by Buhrmester et al. (2011), respondents on MTurk appear to be internally motivated, with motives such as killing time and having fun being rated much higher than the actual compensation received. Nonetheless, MTurk respondents' income levels tend to be shifted toward lower levels (Paolacci et al. 2010). Therefore, segments of interest to the retail investment market, such as High Net Worth Individuals (HNWI), are likely to be under-represented in our sample.

Third, our experiment is a theoretical simplification of the reality faced by retail investors. In the field, investments are generally made through an intermediate: the employer, a physical retail bank, or an online one. This context might influence (positively or negatively) the effects of the nudges we observe in our experiment. For instance, real-world investors might take more time to think about their investments and select them more carefully, given the amounts at 


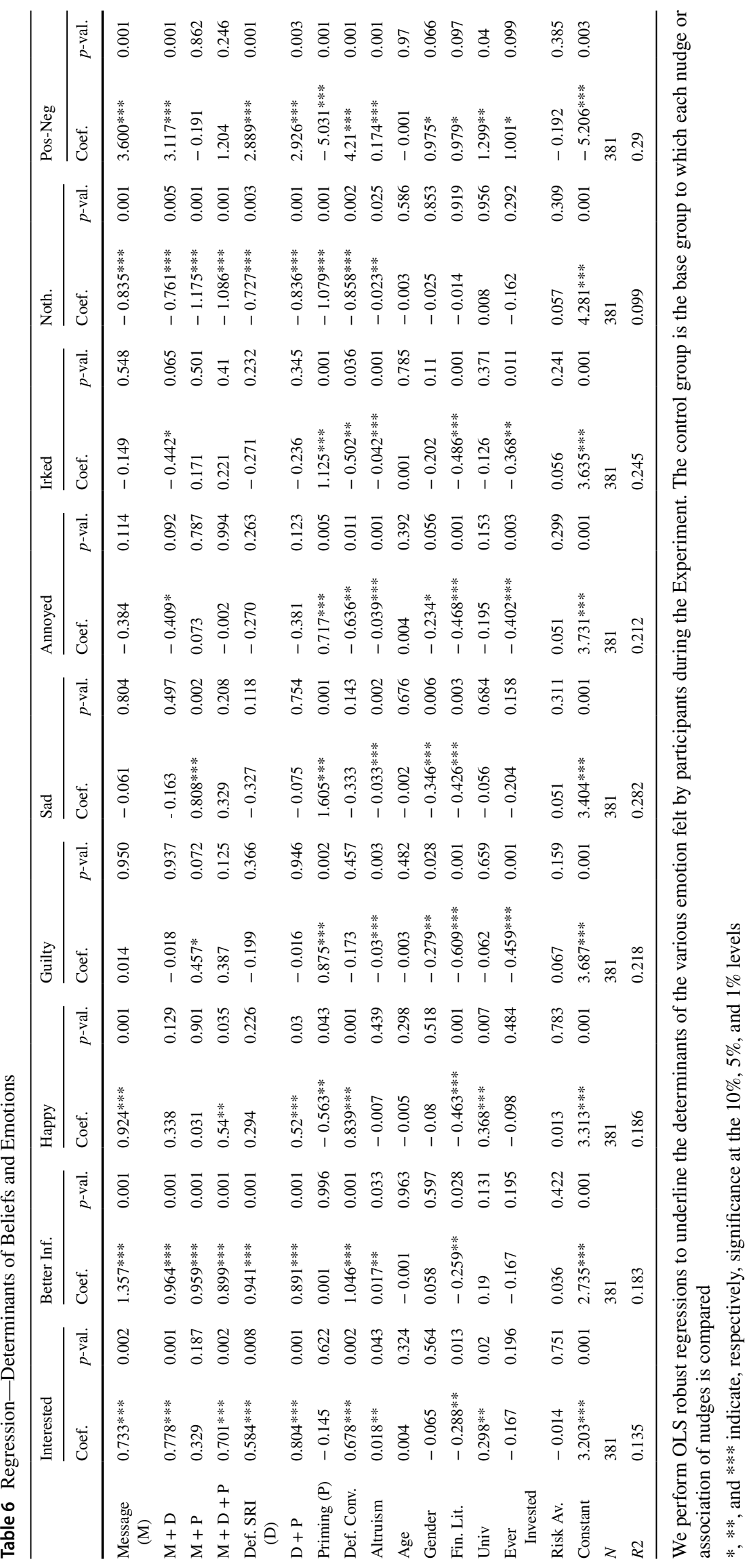


stakes. If the real-world process is more cognitive oriented than the one in our experiment, it could potentially result in a reduction of the effect of the default nudge. Real-world investors are generally faced with a much more complex decision than the one presented in our experiment. If only 4 options were available in our experiment, a multitude is offered in real-world settings, often resulting in cognitive overload (see Pilaj 2017). In such a case, humans often become indecisive, and finally refrain from making a choice at all, falling back to the default (see Tversky and Shafir 1992 or Pilaj 2017). All in all, these limitations call for a follow-up field experiment to confirm the promising results we observed, under real-world conditions.

In terms of policy implications, our findings offer support for the solution proposed by Pilaj (2017), the ECMI ${ }^{5}$, or the UN-PRI ${ }^{6}$, consisting in establishing SRI as a default investment with the possibility of opting out. Our research indicates that such a policy would increase allocation to SRI by more than $40 \%$. Continued research should investigate the actual effects of such a default nudge in real-world conditions. A market actor engaged in CSR could lead the way in performing such a test. This test should of course enable to prove the efficiency of the default nudge in increasing SRI allocation, but also tackle the possibility of any side effects or obstacles related to the implementation of such a policy. If this test proves satisfactory, a regulator could then impose a default SRI allocation for all retail market distributors.

\section{Appendix: Experimental Instructions}

\section{A.1 Altruism Scale}

Investors were asked: To what extent these statements correspond you? Please indicate your choice. Answers were provided on a five point Likert type scale anchored at "Strongly Disagree" and "Strongly Agree" $(\alpha=.77)$.

Positive keyed items:

- Make people feel welcome.

- Anticipate the needs of others.

- Love to help others.

- Am concerned about others.

- Have a good word for everyone.

Negative keyed items:

\footnotetext{
${ }^{5}$ See the ECMI task force on asset allocation report, 2020, p.76: "In order to mainstream sustainable finance, retail investors should be offered sustainable investment products as default options."

${ }^{6}$ See for instance recommendation 8 of the "Fiduciary duty in the 21st century: France roadmap."
}

- Look down on others.

- Am indifferent to the feelings of others.

- Make people feel uncomfortable.

- Turn my back on others.

- Take no time for others.

\section{A.2 Risk Preferences}

Here are 5 lotteries. Each one of them has two possible outcomes, each associated with a probability of $50 \%$. To which lottery would you prefer to play?

\begin{tabular}{llll}
\hline & & $50 \%$ & $50 \%$ \\
\hline Lottery 1 & Potential values & $\$ 30.00$ & $\$ 30.00$ \\
Lottery 2 & Potential values & $\$ 21.25$ & $\$ 40.00$ \\
Lottery 3 & Potential values & $\$ 17.50$ & $\$ 45.00$ \\
Lottery 4 & Potential values & $\$ 12.50$ & $\$ 51.25$ \\
Lottery 5 & Potential values & $\$ 0.00$ & $\$ 60.00$ \\
\hline
\end{tabular}

\section{A.3 Financial Expertise Questions}

Some questions about finance. Do you think the following statement is true or false? "Buying a single company stock usually provides a safer return than a stock mutual fund."

- True

- False

- Refuse to answer

- Do not know

Imagine that the interest rate on your savings account was $1 \%$ per year and inflation was $2 \%$ per year. After 1 year, with the money in this account, would you be able to buy

- More than today

- Exactly the same as today

- Less than today

- Do not know

- Refuse to answer

Suppose you had $\$ 100$ in a savings account and the interest rate was $2 \%$ per year. After 5 years, how much do you think you would have in the account if you left the money to grow:

- More than 102

- Exactly 102

- Less than 102

- Do not know

- Refuse to answer 
Some questions about you and the financial markets... [Answers were 'Yes' or 'No'].

- Have you ever invested on the financial markets?

- Have you ever invested in SRI?

- Do you currently hold investment on the financial markets?

- Do you currently hold investments in SRI?

- Do you read the financial and economic press?

\section{A.4 Investment Game}

Imagine that you have $\$ 10,000$ to invest. Your bank proposes you the 4 funds below. Your task is to choose the percentage you would allocate to each of the 4 funds by clicking and dragging the bars below the description. The total percentage needs to equal $100 \%$.

For each fund, a risk index on a scale of 1 to 7 is indicated, 1 is the least risky, and 7 the riskiest. Similarly, a financial return index on a scale of 1 to 7 is indicated, with 1 being the lowest return and 7 being the highest return.

\begin{tabular}{lll}
\hline Name & Risk & Return \\
\hline Equity fund & 2 & 4 \\
Bond fund & 1 & 2 \\
Index fund & 3 & 6 \\
Socially responsible fund & 3 & 6 \\
\hline Fund & Allocation (\%) \\
\hline Equity fund & $?$ \\
Bond fund & $?$ \\
Index fund & $?$ \\
SR fund & $?$ \\
Total & \multicolumn{2}{l}{} \\
\hline
\end{tabular}

\section{A.5 Default Nudge}

In the default nudge, the Investment game (see Appendix A.4) instructions were slightly modified (modifications in bold):

Imagine that you have $\$ 10,000$ to invest. Your bank is striving for social responsibility and therefore proposes by default only Socially Responsible Funds. It proposes you the allocation below If you agree just click next. However, if you want to invest in some of the other funds, please tick the box below and sign in the next page.
For each fund, a risk index on a scale of 1 to 7 is indicated, 1 is the least risky, and 7 the riskiest. Similarly, a financial return index on a scale of 1 to 7 is indicated, with 1 being the lowest return and 7 being the highest return.

\begin{tabular}{lll}
\hline Name & Risk & Return \\
\hline Equity fund & 2 & 4 \\
Bond fund & 1 & 2 \\
Index fund & 3 & 6 \\
Socially responsible fund & 3 & 6 \\
\hline Fund & Allocation (\%) \\
\hline Equity fund & $\mathbf{0}$ \\
Bond fund & $\mathbf{0}$ \\
Index fund & $\mathbf{0}$ \\
SR fund & $\mathbf{1 0 0}$ \\
Total & 100 \\
\hline
\end{tabular}

\section{A.6 Message Nudge}

In the message nudge, investors read:

According to the United Nation Principles for Responsible Investment (The world's leading proponent of Responsible Investment), responsible investment is an approach to investing that aims to incorporate environmental, social, and governance (ESG) factors into investment decisions (Figs. 2, 3 and 4).

The figure was followed by this text:

"It must be noted that the financial performance of Socially Responsible Investments does not differ from the one of conventional investment. As underlined in a scientific article by Von Wallis and Klein (2015): '“'Our metaanalysis shows that most research studies find that socially responsible (SR) investments perform equal to conventional investments'." 
Fig. 3 Materials used for social information in message nudge

Fig. 2 Materials used for Environmental information in message nudge

Fig. 4 Materials used for environmental information in message nudge

\section{A.7 Priming Nudge}

See Fig. 5.

\section{Social}

- working conditions, including slavery and child labour

- local communities, including indigenous communities

- conflict

- health and safety

- employee relations and diversity

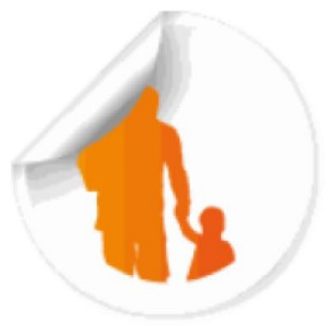

\section{Environmental}

- climate change

- greenhouse gas (GHG) emissions

- resource depletion, including water

- waste and pollution

- deforestation

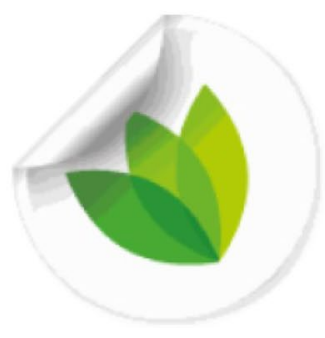

\section{Governance}

- executive pay

- bribery and corruption

- political lobbying and donations

- board diversity and structure

- tax strategy

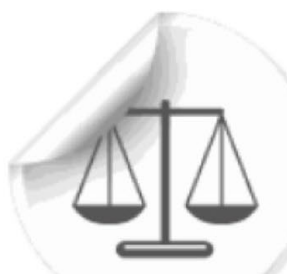

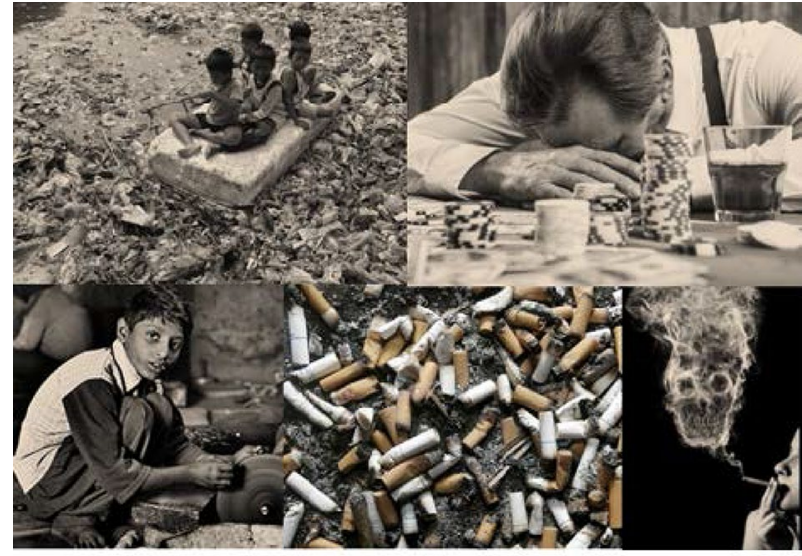

Do you want to profit from this?

Fig. 5 Materials used for affective priming 


\section{A.8 Anchoring Disposition}

This question is a counting problem which has 2 parts. In the first part, you will see a $10 * 10$ matrix that contains the letter " $\mathrm{S}$ " and the number "5." You are asked to guess whether the number of S's is more or fewer than the random number on the screen. Remember that the number you will see is completely random (drawn from a random uniform distribution, which goes from 0 to a 100).

When you made your guess, the matrix will appear again for 10 seconds and you will be asked to write down the exact number of " $S$ " in the matrix.

In order to get a higher score, your guess must be made in the given time and be within 5 of the actual amount of $\mathrm{S}$ in the matrix (Fig, 6).

Are there more or fewer " $\mathrm{S}$ " characters in the matrix below than the random number generated below? 10

- More

- Fewer

You guessed X more than 10 (Fig. 7).
You guessed $\mathrm{X}$ more than 10. Now give us your best guess about how many " $\mathrm{S}$ " characters are in the matrix.

\section{A.9 Measure of Emotions}

Investors were asked: The information provided so far concerning my investment decision made me feel...

Answers were provided on a five-point Likert type scale anchored at "Strongly Disagree" and "Strongly Agree"

- Interested

- Better informed

- Happy

- Guilty

- Sad

- Annoyed

- Irked

- Nothing particular
Fig. 6 Matrix $(10 * 10)$ displayed to participants in phase one
Are there more or fewer "S" characters in the matrix below than the random number generated below?

\section{0}

$\begin{array}{llllllllll}5 & 5 & \mathrm{~S} & \mathrm{~S} & 5 & 5 & \mathrm{~S} & \mathrm{~S} & 5 & 5 \\ 5 & \mathrm{~S} & \mathrm{~S} & \mathrm{~S} & 5 & \mathrm{~S} & \mathrm{~S} & \mathrm{~S} & 5 & \mathrm{~S} \\ 5 & \mathrm{~S} & \mathrm{~S} & \mathrm{~S} & 5 & \mathrm{~S} & \mathrm{~S} & \mathrm{~S} & 5 & \mathrm{~S} \\ 5 & \mathrm{~S} & 5 & \mathrm{~S} & 5 & \mathrm{~S} & 5 & \mathrm{~S} & 5 & \mathrm{~S} \\ \mathrm{~S} & 5 & \mathrm{~S} & 5 & \mathrm{~S} & 5 & \mathrm{~S} & 5 & \mathrm{~S} & 5 \\ \mathrm{~S} & \mathrm{~S} & 5 & \mathrm{~S} & 5 & \mathrm{~S} & 5 & \mathrm{~S} & 5 & \mathrm{~S} \\ \mathrm{~S} & \mathrm{~S} & 5 & \mathrm{~S} & 5 & \mathrm{~S} & 5 & \mathrm{~S} & 5 & \mathrm{~S} \\ \mathrm{~S} & 5 & \mathrm{~S} & \mathrm{~S} & \mathrm{~S} & \mathrm{~S} & \mathrm{~S} & \mathrm{~S} & \mathrm{~S} & \mathrm{~S} \\ \mathrm{~S} & \mathrm{~S} & \mathrm{~S} & \mathrm{~S} & \mathrm{~S} & \mathrm{~S} & \mathrm{~S} & \mathrm{~S} & \mathrm{~S} & \mathrm{~S} \\ \mathrm{~S} & \mathrm{~S} & \mathrm{~S} & \mathrm{~S} & 5 & \mathrm{~S} & 5 & \mathrm{~S} & 5 & \mathrm{~S}\end{array}$

Now you have 10 seconds to count exactly how many "S" characters are in the matrix:
Fig. 7 Matrix $(10 * 10)$ displayed for 10 seconds to participants in phase two

$\begin{array}{llllllllll}5 & 5 & \mathrm{~S} & \mathrm{~S} & \mathbf{5} & \mathbf{5} & \mathrm{S} & \mathrm{S} & \mathbf{5} & \mathbf{5} \\ \mathbf{5} & \mathrm{S} & \mathrm{S} & \mathrm{S} & \mathbf{5} & \mathrm{S} & \mathrm{S} & \mathrm{S} & \mathbf{5} & \mathrm{S} \\ \mathbf{5} & \mathrm{S} & \mathrm{S} & \mathrm{S} & \mathbf{5} & \mathrm{S} & \mathrm{S} & \mathrm{S} & \mathbf{5} & \mathrm{S} \\ \mathbf{5} & \mathrm{S} & 5 & \mathrm{~S} & \mathbf{5} & \mathrm{S} & \mathbf{5} & \mathrm{S} & \mathbf{5} & \mathrm{S} \\ \mathrm{S} & \mathbf{5} & \mathrm{S} & \mathbf{5} & \mathrm{S} & \mathbf{5} & \mathrm{S} & \mathbf{5} & \mathrm{S} & \mathbf{5} \\ \mathrm{S} & \mathrm{S} & 5 & \mathrm{~S} & 5 & \mathrm{~S} & \mathbf{5} & \mathrm{S} & 5 & \mathrm{~S} \\ \mathrm{~S} & \mathrm{~S} & 5 & \mathrm{~S} & 5 & \mathrm{~S} & \mathbf{5} & \mathrm{S} & 5 & \mathrm{~S} \\ \mathrm{~S} & 5 & \mathrm{~S} & \mathrm{~S} & \mathrm{~S} & \mathrm{~S} & \mathrm{~S} & \mathrm{~S} & \mathrm{~S} & \mathrm{~S} \\ \mathrm{~S} & \mathrm{~S} & \mathrm{~S} & \mathrm{~S} & \mathrm{~S} & \mathrm{~S} & \mathrm{~S} & \mathrm{~S} & \mathrm{~S} & \mathrm{~S} \\ \mathrm{~S} & \mathrm{~S} & \mathrm{~S} & \mathrm{~S} & \mathbf{5} & \mathrm{S} & \mathbf{5} & \mathrm{S} & 5 & \mathrm{~S}\end{array}$




\section{Appendix B-Robustness Checks}

See Tables 7 and 8 .

Table 7 Regression underlining the link between "Irked" and total Investment in SRI

\begin{tabular}{|c|c|c|}
\hline & Coef. & P. Val. \\
\hline Message (M) & 1.817 & 0.675 \\
\hline M + default SRI (D) & $44.292 * * *$ & 0.001 \\
\hline $\mathrm{M}+\mathrm{P}$ & $8.791 *$ & 0.055 \\
\hline $\mathrm{M}+\mathrm{D}+$ priming $(\mathrm{P})$ & $47.290 * * *$ & 0.001 \\
\hline $\mathrm{D}$ & $38.583 * * *$ & 0.001 \\
\hline $\mathrm{D}+\mathrm{P}$ & $53.338 * * *$ & 0.001 \\
\hline $\mathrm{P}$ & 6.319 & 0.157 \\
\hline Default conventional & $-8.527^{*}$ & 0.063 \\
\hline Altruism & $0.731 * * *$ & 0.003 \\
\hline Age & -0.041 & 0.740 \\
\hline Men & -3.718 & 0.235 \\
\hline Ever Inv. & $8.356^{* *}$ & 0.025 \\
\hline Fin. Lit. & -1.303 & 0.692 \\
\hline Univ. & -1.788 & 0.595 \\
\hline Risk aversion & -0.080 & 0.953 \\
\hline Irked (Dicho) & $-6.574 *$ & 0.077 \\
\hline Constant & 14.825 & 0.180 \\
\hline$N$ & 381 & \\
\hline$R^{2}$ & 0.406 & \\
\hline
\end{tabular}

This robust OLS regression highlights the determinants of investment in SRI, on the basis of all the respondents in experiment 2. We introduce respondents' self-declared feeling of being irked (dichotomized around 3), to underline the negative relation between this emotion and SRI 
Table 8 Robustness check-Heckman two-step method

\begin{tabular}{|c|c|c|c|c|}
\hline & \multicolumn{4}{|c|}{ Step 2-regressions } \\
\hline & \multicolumn{4}{|c|}{ Robust linear regressions } \\
\hline & \multicolumn{2}{|l|}{ XP 1} & \multicolumn{2}{|l|}{ XP 2} \\
\hline & Coef. & p-val. & Coef. & $p$-val \\
\hline DefaultSRI & $8.956^{* * *}$ & 0.008 & $8.106^{* *}$ & 0.019 \\
\hline Altruism & 1.510 & 0.375 & 0.338 & 0.196 \\
\hline Age & -0.437 & 0.325 & -0.200 & 0.221 \\
\hline Men & -5.518 & 0.653 & $-6.903^{*}$ & 0.073 \\
\hline Ever invested & 9.813 & 0.346 & -3.560 & 0.565 \\
\hline Risk aversion & 1.165 & 0.361 & 0.244 & 0.855 \\
\hline Univ & -14.418 & 0.558 & -6.935 & 0.127 \\
\hline Fin. Lit & 5.013 & 0.294 & 0.305 & 0.940 \\
\hline I.M.R. & -65.206 & 0.527 & -13.802 & 0.259 \\
\hline Constant & 74.137 & 0.478 & $58.905 * * *$ & 0.007 \\
\hline$N$ & 132 & & 152 & \\
\hline \multirow[t]{5}{*}{$R^{2}$} & 0.134 & & 0.114 & \\
\hline & \multicolumn{4}{|c|}{ Step 1 -selection } \\
\hline & \multicolumn{4}{|c|}{ Probit regressions } \\
\hline & \multicolumn{2}{|l|}{ XP 1} & \multicolumn{2}{|l|}{ XP 2} \\
\hline & Coef. & $p$-val. & Coef. & $p$-val \\
\hline DefaultSRI & & & 0.306 & 0.453 \\
\hline Altruism & $-0.027 *$ & 0.098 & 0.032 & 0.314 \\
\hline DefaultSRI*Altruism & & & $-0.063 * * *$ & 0.062 \\
\hline Age & 0.007 & 0.459 & -0.003 & 0.651 \\
\hline Men & 0.185 & 0.392 & -0.090 & 0.640 \\
\hline Ever invested & -0.124 & 0.632 & $-0.432 * *$ & 0.042 \\
\hline Risk aversion & -0.007 & 0.935 & 0.009 & 0.903 \\
\hline Univ. & $0.388 *$ & 0.083 & -0.099 & 0.629 \\
\hline Fin. Lit. & 0.047 & 0.834 & 0.143 & 0.476 \\
\hline Constant & -0.360 & 0.648 & 0.693 & 0.369 \\
\hline$N$ & 161 & & 212 & \\
\hline Pseudo $R^{2}$ & 0.0473 & & 0.045 & \\
\hline
\end{tabular}

This table contains the results of the two-step Heckman procedure for experiments 1 and 2. We first perform a probit regression on the probability to refuse the default, then compute the inverse mills ratio, which we enter into the second regression pertaining to participants who refused the default allocation, compared with the control group. Results remain essentially unchanged 
Acknowledgements We would like to thank participants of the JBE Publishing workshop 2019, Lyon, as well as participants of the Lyon University Research Seminar, and the Panorisk workshop 2019, Angers, in which this paper was presented and received a number of comments that significantly improved it. While the conference was canceled due to the global pandemic, we would like to thank the organizers of the Austrian Innsbruck Winter Summit, 2020, who were kind enough to accept our paper and did their utter best to maintain the conference. Finally, we wish to extend special thanks to Sabri Boubaker for his insightful comments, which greatly improved the paper. The work hereby presented to you has been made possible thanks to the financial support of the University of Lyon's Project IDEXLYON in the framework of the PIA (Programme Investissements d'Avenir (ANR-16-IDEX-0005)).

Open Access This article is licensed under a Creative Commons Attribution 4.0 International License, which permits use, sharing, adaptation, distribution and reproduction in any medium or format, as long as you give appropriate credit to the original author(s) and the source, provide a link to the Creative Commons licence, and indicate if changes were made. The images or other third party material in this article are included in the article's Creative Commons licence, unless indicated otherwise in a credit line to the material. If material is not included in the article's Creative Commons licence and your intended use is not permitted by statutory regulation or exceeds the permitted use, you will need to obtain permission directly from the copyright holder. To view a copy of this licence, visit http://creativecommons.org/licenses/by/4.0/.

\section{References}

Ackert, L. F., Church, B. K., \& Qi, L. (2016). An experimental examination of portfolio choice. Review of Finance, 20(4), 1427-1447.

Ajzen, I. (1991). The theory of planned behavior. Organizational Behavior and Human Decision Processes, 50(2), 179-211.

Ajzen, I. (2001). Nature and operation of attitudes. Annual Review of Psychology, 52(1), 27-58.

Alba, J., \& Hutchinson, W. (1987). Dimensions of consumer expertise. Journal of Consumer Research, 13(4), 411-454.

Ambec, S., \& Lanoie, P. (2008). Does it pay to be green? A systematic overview. Academy of Management Perspectives, 22, 45-62.

Ariely, D., Bracha, A., \& Meier, S. (2009). Doing good or doing well? Image motivation and monetary incentives in behaving prosocially. American Economic Review, 99(1), 544-555.

Ayres, I., \& Gertner, R. (1989). Filling gaps in incomplete contracts: An economic theory of default rules. Yale $L J, 99,87-130$.

Baldwin, R. (2014). From regulation to behaviour change: Giving nudge the third degree. Modern Law Review, 77(6), 831-857.

Baron, J., \& Ritov, I. (1994). Reference points and omission bias. Organizational Behavior and Human Decision Processes, 59(3), 475-498.

Barrick, M., \& Mount, M. (1991). The big five personality dimensions and job performance: A meta-analysis. Personnel Pychology, 44(1), 1-26.

Bauer, R., Derwall, J., \& Otten, R. (2007). The ethical mutual fund performance debate: New evidence from Canada. Journal of Business Ethics, 70, 111-124.

Bazerman, M., \& Sezer, O. (2016). Bounded awareness: Implications for ethical decision making. Organizational Behavior and Human Decision Processes, 136, 95-105.

Beal, D., Goyen, M., \& Philips, P. (2005). Why do we invest ethically? Journal of Investing, 14(3), 66-77.
Berg, L. (2007). Competent consumers? Consumer competence profiles in Norway. International Journal of Consumer Studies, 31(4), 418-427.

Buhrmester, M., Kwang, T., \& Gosling, S. (2011). Amazon's mechanical turk: A new source of inexpensive, yet high-quality, data? Perspectives on Psychological Science, 6(1), 3-5.

Capon, N., Fitzsimons, G., \& Prince, R. (1996). An individual level analysis of the mutual fund investment decision. Journal of Financial Services Research, 10(1), 59-83.

Chan, K. (1999). Market segmentation of green consumers in Hong Kong. Journal of International Consumer Marketing, 12(2), 7-24.

Chang, C. (2011). Guilt appeals in cause-related marketing: The subversive roles of product type and donation magnitude. International Journal of Advertising, 30(4), 587-616.

Chater, N., Huck, S., \& Inderst, R. (2010). Consumer Decision-Making in Retail Investment Services : A Behavioural Economics Perspective Final Report. Report to the European Commission/SANCO (November).

Davidai, S., Gilovich, T., \& Ross, L. (2012). The meaning of default options for potential organ donors. Proceedings of the National Academy of Sciences, 109(38), 15201-15205.

Delton, W., Krasnow, M., Cosmides, L., \& Tooby, J. (2011). Evolution of direct reciprocity under uncertainty can explain human generosity in one-shot encounters. Proceedings of the National Academy of Sciences, 108(32), 13335-13340.

Diamantopoulos, A., Schlegelmilch, B., Sinkovics, R., \& Bohlen, G. (2003). Can socio-demographics still play a role in profiling green consumers? A review of the evidence and an empirical investigation. Journal of Business Research, 56(6), 465-480.

Dinner, I., Johnson, E., Goldstein, D., \& Liu, K. (2011). Partitioning default effects: Why people choose not to choose. Journal of Experimental Psychology: Applied, 17(4), 332.

Eurosif. (2018). European SRI Study 2018 (Tech. Rep.).

Filbeck, G., Hatfield, P., \& Horvath, P. (2005). Risk aversion and personality type. The Journal of Behavioral Finance, 6(4), 170-180.

Forum for Sustainable \& Responsible Investment. (2018). Sustainable investing assets reach $\backslash \$ 12$ trillion as reported by the us sif foundation's biennial report on us sustainable, responsible and impact investing trends [press release].

Gigerenzer, G. (2008). Why heuristics work. Perspectives on Psychological Science, 3(1), 20-29.

Gino, F., Schweitzer, M., Mead, N., \& Ariely, D. (2011). Organizational behavior and human decision processes unable to resist temptation: How self-control depletion promotes unethical behavior. Organizational Behavior and Human Decision Processes, 115(2), 191-203.

Glac, K. (2009). Understanding socially responsible investing: The effect of decision frames and trade-off options. Journal of Business Ethics, 87(1), 41-55.

Goldberg, L., Johnson, J., Eber, H., Hogan, R., Ashton, M., Cloninger, R., et al. (2006). The international personality item pool and the future of public-domain personality measures. Journal of Research in Personality, 40(1), 84-96.

Griskevicius, V., Tybur, J., \& Van den Bergh, B. (2010). Going green to be seen: status, reputation, and conspicuous conservation. Journal of Personality and Social Psychology, 98(3), 392-404.

Gunaratne, J., \& Nov, O. (2015). Informing and Improving Retirement Saving Performance using Behavioral Economics Theory-driven User Interfaces. Working Paper (January) 917-920.

Henrich, J., Boyd, R., Bowles, S., Camerer, C., Fehr, E., Gintis, H., \& Tracer, D. (2005). "Economic man" in cross-cultural perspective: Behavioral experiments in 15 small-scale societies. Behavioral and Brain Sciences, 28(6), 795-855.

Heyman, J., \& Ariely, D. (2004). Effort for payment. A tale of two markets. Psychological Science, 15(11), 787-93. 
Hockerts, K., \& Moir, L. (2004). Communicating corporate responsibility to investors: The changing role of the investor relations function. Journal of Business Ethics, 52, 85-98.

Hofmann, E., Hoelzl, E., \& Kirchler, E. (2008). A comparison of models describing the impact of moral decision making on investment decisions. Journal of Business Ethics, 82(1), 171-187.

Hofmann, E., Meier-Presti, K., Kirchler, E., \& Meier-Pesti, K. (2007). The decision process for ethical investment. Journal of Financial Services Marketing, 12(1), 4-16.

Hummels, H., \& Timmer, D. (2004). Investors in need of social, ethical, and environmental information. Journal of Business Ethics, $52,73-84$

Isen, A., \& Noonberg, A. (1979). The effect of photographs of the handicapped on donation to charity: When a thousand words may be too much. Journal of Applied Social Psychology, 9(5), 426-431.

Jahedi, S., Deck, C., \& Ariely, D. (2017). Arousal and economic decision making. Journal of Economic Behavior \& Organization, 134, 165-189.

Jansson, M., \& Biel, A. (2009). Psychological Influences on Investors Intention to be Socially Responsible Investors: A comparison what influences SRI intentions among different types of investors. Working paper

Johnson, E. (2008). Man, my brain is tired: Linking depletion and cognitive effort in choice. Journal of Consumer Psychology, 18(1), $14-16$.

Johnson, E., \& Goldstein, D. (2003). Do defaults save lives? Science, 302(5649), 1338.

Jones, T. (1991). Ethical decision making by individuals in organizations: An issue-contingent model. The Academy of Management Review, 16(2), 366-395.

Kahneman, D. (2003). Maps of bounded rationality: Psychology for behavioral economics. The American Economic Review, 93(5), 1449-1475.

Kahneman, D. (2011). Thinking, fast and slow. London: Macmillan.

Kahneman, D., Knetsch, J., \& Thaler, R. (1991). Anomalies the endowment effect, loss aversion, and status quo bias. Journal of Economic Perspectives, 5(1), 193-206.

Kouchaki, M., \& Smith, I. (2014). The morning morality effect: The influence of time of day on unethical behavior. Psychological Science, 25(1), 95-102.

Kouchaki, M., Smith-crowe, K., Brief, A., \& Sousa, C. (2013). Organizational behavior and human decision processes seeing green: Mere exposure to money triggers a business decision frame and unethical outcomes. Organizational Behavior and Human Decision Processes, 121(1), 53-61.

Landman, J. (1987). Regret and elation following action and inaction: Affective responses to positive versus negative outcomes. Personality and Social Psychology Bulletin, 13(4), 524-536.

Laroche, M., Bergeron, J., \& Barbaro-Forleo, G. (2001). Targeting consumers who are willing to pay more for environmentally friendly products. Journal of Consumer Marketing, 18(6), 503-520.

Lee, K. (2009). Gender differences in Hong Kong adolescent consumers' green purchasing behavior. Journal of Consumer Marketing, 26(2), 87-96.

Lewis, A., \& Mackenzie, C. (2000). Morals, money, ethical investing and economic psychology. Human Relations, 53(2), 179-191.

Lewis, A., \& Webley, P. (1994). Social and ethical investing. Ethics and economic affairs (pp. 171-182). London: Routledge.

Majoch, A. A., Hoepner, A. G., \& Hebb, T. (2017). Sources of stakeholder salience in the responsible investment movement: Why do investors sign the principles for responsible investment? Journal of Business Ethics, 140(4), 723-741.

Markowitz, H. (1952). Portfolio selection. The Journal of Finance, 7(1), 77-91.
May, D., \& Pauli, K. (2003). The role of moral intensity in ethical decision making. Business \& Society, 41(1), 84-117.

Mazar, N., Amir, O., \& Ariely, D. (2008). The dishonesty of honest people: A theory of self-concept maintenance. Journal of Marketing Research, 45(6), 633-644.

McKenzie, C., Liersch, M., \& Finkelstein, S. (2006). Recommendations implicit in policy defaults. Psychological Science, 17(5), 414-420.

Mclachlan, J., \& Gardner, J. (2004). A comparison of socially responsible and conventional investors. Journal of Business Ethics, 52(11-25), 11-25.

Meyers, D. (2008). Psychology. New York: Springer.

Nilsson, J. (2008). Investment with a conscience: Examining the impact of pro-social attitudes and perceived financial performance on socially responsible investment behavior. Journal of Business Ethics, 83, 307-325.

Nilsson, J. (2009). Segmenting socially responsible mutual fund investors: The influence of financial return and social responsibility. International Journal of Bank Marketing, 27(1), 5-31.

Nilsson, J. (2010). Consumer decision making in a complex environment: Examining the decision making process of socially responsible mutual fund investors (Unpublished 686 doctoral dissertation). Umeå: Umeå School of Business, Umeå University.

Paetzold, F., \& Busch, T. (2014). Cognitive barriers to sustainable investing: Unleashing the power of wealthy private investors. Organization \& Environment, 27(4), 347-367.

Pålsson, A. (1996). Does the degree of relative risk aversion vary with household characteristics? Journal of Economic Psychology, 17(6), 771-787.

Paolacci, G., Chandler, J., \& Stern, L. (2010). Running experiments on Amazon Mechanical Turk. Judgment and Decision Making, 5(5), 411-419.

Paribas, B. (2018). Attitudes Toward Socially Responsible Investment in Europe (Tech. Rep.).

Penner, L., \& Finkelstein, M. (1998). Dispositional and structural determinants of volunteerism. Journal of Personality and Social Psychology, 74(2), 525-537.

Perrine, R., \& Heather, S. (2000). Effects of picture and even-a-pennywill-help appeals on anonymous donations to charity. Psychological Reports, 86(2), 551-559.

Pilaj, H. (2017). The Choice architecture of sustainable and responsible investment: Nudging investors toward ethical decision-making. Journal of Business Ethics, 140(4), 743-753.

Pinatton, J., \& Amariei, C. (2020). ECMI Task Force on Asset Allocation in Europe (Tech. Rep.).

Renneboog, L., Ter Horst, J., \& Zhang, C. (2008). Socially responsible investments: Institutional aspects, performance, and investor behavior. Journal of Banking \& Finance, 32(9), 1723-1742.

Riedl, A., \& Smeets, P. (2017). Why do investors hold socially responsible mutual funds? The Journal of Finance, 72(6), 2505-2550.

Ritov, I., \& Baron, J. (1992). Status-quo and omission biases. Journal of Risk and Uncertainty, 5(1), 49-61.

Rubaltelli, E., Lotto, L., Ritov, I., \& Rumiati, R. (2015). Moral investing: Psychological motivations and implications. Judgment and Decision Making, 10(1), 64-75.

Samuelson, W., \& Zeckhauser, R. (1988). Status quo bias in decision making. Journal of Risk and Uncertainty, 1(1), 7-59.

Sandberg, J., Juravle, C., Hedesstro, T., \& Hamilton, I. (2009). The heterogeneity of socially responsible investment. Journal of Business Ethics, 87, 519-533.

Schneider, S., \& Lopes, L. (1986). Reflection in preferences under risk: Who and when may suggest why. Journal of Experimental Psychology: Human Perception and Performance, 12(4), 535-548.

Schooley, D., \& Worden, D. (1996). Risk aversion measures: Comparing attitudes and asset allocation. Financial Services Review, $5(2), 87-99$. 
Shalvi, S., Eldar, O., \& Bereby-Meyer, Y. (2012). Honesty requires time (and lack of justifications). Psychological Science, 23(10), 1264-70.

Shu, L., Gino, F., \& Bazerman, M. (2011). Dishonest deed, clear conscienc: When cheating leads to moral disengagement and motivated forgetting. Personality and Social Psychology Bulletin, 37(3), 330-349.

Sunstein, C. (2015). Choosing not to choose: Understanding the value of choice. Oxford: Oxford University Press.

Thaler, R. (2000). From homo economicus to homo sapiens. Journal of Economic Perspectives, 14(1), 133-141.

Thaler, R. (2015). The power of nudges, for good and bad. The New York Times, 31, 2015.

Thaler, R., \& Sunstein, C. (2008). Nudge: Improving decisions about health, wealth, and happiness. New Haven, CT: Yale University Press.

Tversky, A., \& Kahneman, D. (1974). Judgment under uncertainty: Heuristics and biases. Science, 185, 1124-1131.

Tversky, A., \& Kahneman, D. (1981). The framing of decisions and the psychology of choice. Science, 211(4481), 453-458.

Tversky, A., \& Kahneman, D. (1991). Loss aversion in riskless choice: A reference-dependent model. The Quarterly Journal of Economics, 106(4), 1039-1061.

Tversky, A., \& Kahneman, D. (1992). Advances in prospect theory: Cumulative representation of uncertainty. Journal of Risk and uncertainty, 5(4), 297-323.

Tversky, A., \& Shafir, E. (1992). Choice under conflict: The dynamics of deferred decision. Psychological Science, 3(6), 358-361.
Valor, C., \& Fernandez, B. (2009). Understanding demand for retail socially responsible investments: A survey of individual. Corporate Social Responsibility and Environmental Management, 14, $1-14$.

Vohs, K., Mead, N., \& Goode, M. (2006). The psychological consequences of money. Science, 314(5802), 1154-1156.

Vohs, K., Mead, N., \& Goode, M. (2008). Merely activating the concept of money changes personal and interpersonal behavior. Current Directions in Psychological Science, 17(3), 208-212.

Von Wallis, M., \& Klein, C. (2015). Ethical requirement and financial interest: A literature review on socially responsible investing. Business Research, 8(1), 61-98.

Vyvyan, V., Ng, C., \& Brimble, M. (2007). Socially responsible investing: The green attitudes and grey choices of australian investors. Corporate Governance: An International Review, 15(2), 370-381.

Wang, H., \& Hanna, S. (1997). Does risk tolerance decrease with age? Financial Counseling and Planning, 8(2), 27-31.

Welsh, D., \& Ordonez, L. (2014). Conscience without cognition: The effects of subconscious priming on ethical behavior. Academy of Management Journal, 57(3), 723-742.

Williams, G. (2007). Some determinants of the socially responsible investment decision: A cross-country study. The Journal of Behavioral Finance, 8(1), 43-57.

Publisher's Note Springer Nature remains neutral with regard to jurisdictional claims in published maps and institutional affiliations", (in PDF at the end of the article below the references; in XML as a back matter article note. 